\title{
TINGKAT RISIKO HARGA CABAI MERAH BESAR DI PROVINSI JAWA BARAT
}

\author{
Nesa Volantina*, Budhi Wahyu Fitriadi, Reny Hidayati \\ Universitas Perjuangan Tasikmalaya, Kadipaten, Kota Tasikmalaya, Indonesia \\ Email : nesavolantina58@gmail.com
}

Naskah diterima: 3 Juni 2021 Direvisi: 27 Juli 2021 Disetujui terbit: 30 Agustus 2021

\begin{abstract}
Price fluctuations in the commodity of big red chili in West Java Province always occur. With the price fluctuations, it can affect the risk of accepted price. Sometimes the proce is high, but in the near future in can drop drastically. Throughout 2017-2021 in West Java Province, big red chili had the lowest price of IDR $25,900 / \mathrm{kg}$ while the highest price was IDR $73,800 / \mathrm{kg}$. This study aims to analyze the level of price risk and the factors that influence the level of price risk of big red chili in West Java Province. This study used secondary data in the form of monthly prices of big red chili for the period of January 2017-June 2021. The data was analyzed by using coefficients of variation and multiple liniear regression. The results showed that the risk level of big red chili prices in West Java Province included a high price risk. The factors that influence the risk of chili prices are the production, the population, the price of substitute curly red chili, the income, the consumer demand, and the previous chili price.
\end{abstract}

Keywords: Big red chili, price risk

Abstrak
Fluktuasi harga yang terjadi pada komoditas cabai merah besar di Provinsi Jawa Barat selalu terjadi. Dengan adanya fluktuasi harga tersebut maka selalu dihadapkan dengan adanya risiko harga yang diterima. Sewaktu-waktu harga sangat tinggi tetapi dalam waktu dekat harga dapat turun secara drastis. Sepanjang tahun 2017-2021 cabai merah besar di Provinsi Jawa Barat harga terendah sebesar $25.900 / \mathrm{kg}$ sedangkan harga tertinggi Rp. $73.800 / \mathrm{kg}$. Penelitian ini bertujuan untuk menganalisis tingkat risiko harga dan factor-faktor yang mempengaruhi tingkat risiko harga cabai merah besar di Provinsi Jawa Barat. Penelitian ini menggunakan data sekunder berupa harga bulanan cabai merah besar periode Januari 2017-Juni 2021. Analisis data yang digunakan yaitu menghitung koefisien variasi serta regresi linier berganda. Hasil penelitian menunjukan bahwa tingkat risiko harga cabai merah besar di Provinsi Jawa Barat cenderung tinggi. Faktor-faktor yang mempengaruhi risiko harga cabai yaitu faktor harga cabai merah kriting substitusi, pendapatan, dan permintaan konsumen berpengaruh positif, sedangkan faktor jumlah produksi dan harga cabai sebelumnya berpengaruh negatif.

Kata Kunci: Cabai merah besar, risiko harga

\section{PENDAHULUAN}

Salah satu tanaman hortikultura

yang banyak dibudidaya di Indonesiaa

yaitu cabai merah besar. Cabai merah

besar merupakan komoditas primadona

masyarakat Indonesia yang digunakan di

berbagai kalangan, serta menjadi ciri khas

dari kuliner Indonesia yang terkenal

pedas. Cabai merah besar menajdi komoditas dengan jumlah produksi

terbesar ke tiga di Indonesia. Menurut

BPS (2020) hasil produksi cabai merah

besar secara nasional sebanyak 1.214.418 ton.

Provinsi Jawa Barat menjadi provinsi dengan nilai produksi terbesar di Indonesia dengan jumlah produksi sebesar 263.949 ton pada tahun 2019 (BPS, 
2020). Meskipun angka produksi menunjukan nilai yang tinggi, namun tingkat produksi tinggi pun dapat menimbulkan kerugian apabila tidak dapat terserap oleh pasar. Kelebihan pasokan ini justru dapat menurunkan harga cabai merah besar. Siklus kebutuhan cabai merah besar sering meningkat menjelang waktu-waktu tertentu, seperti hai-hari besar keagamaan. Adanya peristiwa-peristiwa ini yang dapat menjadikan adanya fluktuasi harga cabai merah besar. Fluktuasi harg rata-rata komoditas cabai merah besar di Provinsi Jawa Barat pada periode Januari 2017-Juni 2021 disajikan pada Gambar 1.

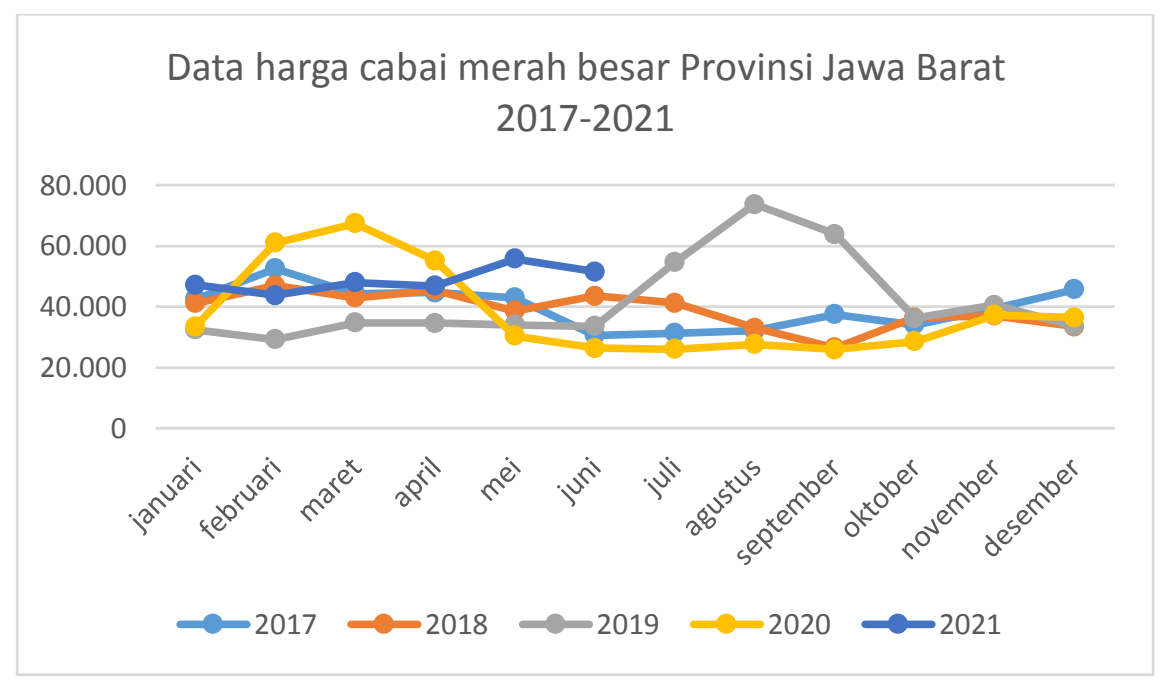

Gambar 1. Data harga cabai merah besar di Provinsi Jawa Barat 2017-2021

Berdasarkan Gambar 1. Dapat dilihat terjadi fluktuasi harga yang cenderung tinggi. Kondisi ini dapat dilihat dari selisih harga terendah dan harga tertinggi yang cukup besar. Harga terendah berada pada harga Rp. 25.900 per kilogram pada bulan September 2020. Sedangkan harga terttinggi sebesar Rp. 73.800 per kilogram pada Agustus 2019. Perbedaan harga tertinggi dan harga terendah adalah Rp. 47.900 atau sebesar 148,9\% dari harga terendah (Priangan Portal Informasi Harga Pangan Jawa Barat, 2021).

Berdasarkan data tersebut dapat dilihat bahwa fluktuasi harga terjadi pada komoditas cabai merah besar. Harga produk yang berfluktuasi secara tajam tidak menguntungkan bagi petani karena menyebabkan ketidakpastian penerimaan dari kegiatan usahatani. Sedangkan fluktuasi harga yang tinggi juga memberikan peluang kepada pedagang untuk memanipulasi informasi harga di tingkat petani. Dengan adanya fluktuasi harga maka di indikasi adanya risiko harga cabai merah besar. Dengan adanya fluktuasi harga menjadi indicator adanya risiko harga (Siahaan, 2013). Risiko usaha yang diterima bisa terjadi semakin besar jika harga produk yang dihadapi semakin berfluktuasi (Rahmawati \& Fariyanti, 2018). 
Kemunculan risiko pada usahatani dapat pula disebabkan oleh beberapa faktor penyebab. Jika terjadi kenaikan maupun penurunan harga berarti ada faktor yang menyebabkan harga cabai tersebut berubahubah. Faktor yang mempengaruhi adanya fluktuasi harga yaitu faktor permintaan dan faktor penawaran. Permintaan dan penawaran pada ilmu ekonomi merupakan suatu gambaran dari hubungan-hubungan yang terjadi di pasar, antara penjual dan calon pembeli pada suatu barang. Permintaan adalah sejumlah barang yang dibeli atau diminta pada suatu harga dan waktu tertentu. Sedangkan penawaran adalah sejumlah barang yang dijual atau ditawarkan pada suatu harga dan waktu tertentu (Aisyah \& Hiola, 2016).

Menurut penelitian Palar et al (2016) salah satu faktor yang mempengaruhi risiko harga cabai yakni harga komoduitas substitusi (pengganti). Apabila komoditas utama naik maka penjual akan meningkatkan jumlah komoditas substitusi dengan harapan para konsumen akan beralih pada komoditas substitusi. Dari sisi permintaan faktor yang mempengaruhi terjadinya risiko harga yaitu jumlah produksi, harga cabai merah sebelumnya, pendapatan, jumlah penduduk dan jumlah permintaan cabai yang diminta konsumen waktu tertentu dan pada tingkat harga dapat mempengaruhi harga cabai. Sedangkan sisi penawaran yaitu harga bawang merah komplementer, harga cabai merah kriting substitusi, dan harga produsen cabai.
Berdasarkan uraian diatas maka tujuan dari penelitian ini yaitu: 1) menganalisis tingkat risiko harga cabai merah besar di Provinsi Jawa Barat, 2) menganalisis faktor-faktor yang mempengaruhi risiko harga cabai merah besar di Provinsi Jawa Barat.

\section{METODE PENELITIAN}

Penelitian ini dilakukan dengan metode analisis deskriptif dan analisis kuantitatif statistic. Data yang dikumpulkan menggunakan instrument penelitian, menganalisis data yang bersifat statistic (Sriyadi, 2014). Lokasi penelitian ditentukan secara sengaja (purposive) yaitu di Provinsi Jawa Barat dengan pertimbangan bahwa provinsi Jaw Barat sebagai sentra produksi cabai merah besar terbesar di Indonesia. Data yang digunakan merupakan data sekunder yaitu data harga rata-rata perbulan cabai merah besar di Provinsi Jawa Barat pada periode Januari 2017-Juni 2021. Perolehan data sekunder melalui website resmi PIHP Provinsi Jawa Barat dan website instansi yang terkait dalam penelitian ini.

Pengumpulan data merupakan teknik atau cara yang dilakukan unrtuk mengumpulkan data melalui beberapa alat seperti wawancara, pengamatan, tes, dokumentasi dan sebagainya utnuk melakukan penelitian (Sekaran, 2016). Teknik pengumpulan data menggunakan teknik: 1) observasi, yaitu dengan melakukan pengamatan secara tidak langsung dengan membuka website PIHP Jaw Barat dan instansi lainnya, 2) studi pustaka, yaitu 
dengan mengunmpulkan literature kepustakaan, 3) Dokumentasi, dengan pengumpulan data yang digunakan dengan form catatan atau dokumen yang tersedia.

Metode analisis data dilakukan dengan menggunakan bantuan Microsoft Excel dan program SPSS versi 21. Untuk menganalisis tingkat risiko harga menggunakan penghitungan koefisien variasi. Koefisien variasi adalah perbandingan antara simpangan baku dengan nilai yang diharapkan. Koefisien variasi dirumuskan sebagai berikut :

$$
\begin{aligned}
& \mathrm{CV}=\frac{\sigma_{\mathrm{i}}}{E(P)} \ldots \ldots \ldots \ldots \\
& \mathrm{E}(\mathrm{P})=\sum_{i=1}^{n} p i P i \ldots \ldots \\
& \text { Keterangan : } \\
& \mathrm{CV} \quad=\text { koefisien variasi } \\
& \mathrm{O}_{\mathrm{i}} \quad=\text { simpangan baku } \\
& \mathrm{E}(\mathrm{P}) \quad=\text { expected return }
\end{aligned}
$$

$$
\begin{aligned}
\mathrm{P} \quad= & \text { harga } \\
\mathrm{p} \quad= & \text { peluang } \\
\mathrm{i} \quad= & \text { kejadian }(1,2,3 \ldots, \mathrm{n}) \\
& \text { semakin besar niali koefisien variasi }
\end{aligned}
$$

$(\mathrm{CV})$, menunjukan semakin besar pula risiko yang diterima. Penentuan besar kecilnya tingkat risiko menggunakan kriteria. Apbila nilai $\mathrm{CV}<1$, maka risiko yang diterima kecil, jika nilai $\mathrm{CV}>1$, maka tingkat risiko yang diterima besar. Selanjutnya analisis kuantitatif dilakukan untuk menganalisis faktor-faktor yang mempengaruhi risiko harga cabai merah besar menggunakan regresi linier berganda.

Regresi linier berganda untuk mendapatkan pengaruh dua atau lebih variable bebas terhadap variable terikat. Untuk keperluan analisis, variable bebas akan dinyatakan dengan $\mathrm{X}$ sedangkan variable tidak bebas dinyatakan dengan $Y$. model regresi linier berganda yaitu :

$$
Y=\alpha+\beta 1 X 1+\beta 2 X 2+\beta 3 X 3+\beta 4 X 4+\beta 5 X 5+\beta 6 X 6+\beta 7 X 7+\beta 8 X 8+\varepsilon \ldots . .(3)
$$

Keterangan :

$\mathrm{Y} \quad=$ Risiko harga cabai merah besar

$\mathrm{X} 1=$ Produksi cabai besar $(\mathrm{Kg})$

$\mathrm{X} 2=$ Harga produsen cabai merah besar $(\mathrm{Rp} / \mathrm{Kg})$

$\mathrm{X} 3=$ jumlah penduduk (jiwa)

$\mathrm{X} 4=$ Harga bawang merah komplementer $(\mathrm{Rp} / \mathrm{Kg})$

$\mathrm{X} 5=$ Harga cabai keriting merah substitusi $(\mathrm{Rp} / \mathrm{Kg})$

$\mathrm{X} 6=$ Pendapatan penduduk

$\mathrm{X} 7 \quad=$ Permintaan konsumen

Yn-1 = Harga cabai merah besar sebelumnya $(\mathrm{Rp} / \mathrm{Kg})$

$\varepsilon \quad=$ error

$\beta 1, \beta 2,=$ koefisien parameter dugaan $X 1$, $\mathrm{X} 2, .$.

$\alpha \quad=$ Koefisien regresi

\section{HASIL DAN PEMBAHASAN}

\section{Tingkat Risiko Harga}

Penilaian risiko harga komoditas cabai merah besar berdasarkan pada deskripsi statistic yaitu ukuran standar deviasi dan koefisien variasi. Hasil perhitungan nilai koefisien variasi, dapat diketahui bahwa komoditas cabai merah besar di Provinsi Jawa Barat memiliki risiko harga. Risiko harga ini terbentuk atas adanya ketidakpastian dan ketidakstabilan harga. Risiko harga dalam sector 
pertanian terjadi akibat adanya fluktuasi, baik itu hasil produksi maupun harga (Shinta, 2011). Deskripsi statistik mengenai tingkat risiko cabai merah besar periode Januari 2017-Juni 2021 dapat dilihat pada Gambar 2.

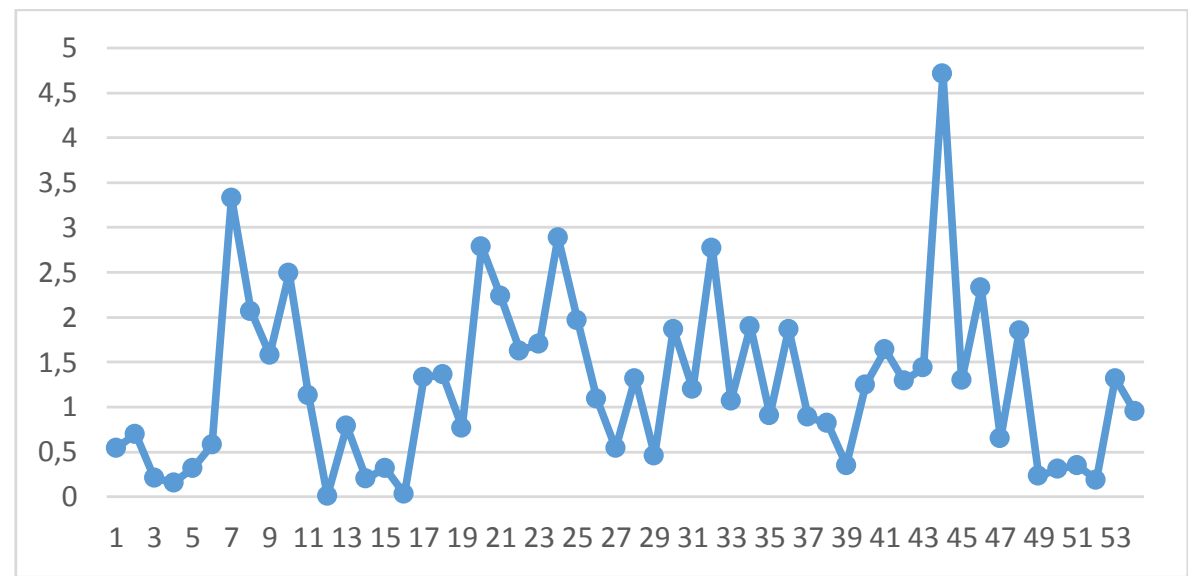

Gambar 2. Hasil tingkat risiko harga cabai merah besar

Berdasarkan Gambar 2, terlihat bahwa tingkat risiko harga cabai merah besar memiliki nilai koefisien yang beragam. Koefisien terendah yaitu sebesar 0,1 pada bulan April 2018, sedangkan tertinggi sebesar 4,7 pada bulan September 2020. Rata-rata koefisien variasi sebesar 1,3 yang berarti bahwa tingkat risiko harga cabai merah besar di Provinsi Jawa Barat tergolong tinggi. Nilai koefisien variasi lebih besar dari 1 maka, suatu komoditas memiliki risiko harga yang tinggi. Sebaliknya apabila nilai koefisien variasi lebih kecil dari 1 maka, nilai risiko harga yang rendah.

Hasil perhitungan nilai koefisien variasi, dapat diketahui bahwa komoditas cabai merah besar di Provinsi Jawa Barat memiliki risiko harga. Risiko harga ini terbentuk atas adanya ketidakpastian dan ketidakstabilan harga. Menurut Shinta (2011) risiko dalam sector pertanian adalah adanya fluktuasi, baik itu hasil produksi maupun harga. Sejalan dengan Siahaa (2016) dan Mohammed et al (2016) menyebutkan dengan terjadinya fluktuasi harga maka dapat menyebabkan risiko bagi para petani maupun konsumen.

Penentuan tingkat risiko harga cabai merah besar menggunakan nilai koefisien variasi dengan menggunakan data harga rata-rata perbulan periode Januari 2017-Juni 2021. Berdasarkan gambar 2, menunjukan bahwa tingkat risiko tertinggi untuk komoditas cabai merah besar sebesar 4,7 pada September 2020. Periode tersebut memiliki tingkat risiko tertinggi karena pada saat itu permintaan cabai yang cukup besar. Hal 
ini sejalan dengan penelitian Salim (2016) menyatakan bahwa apabila nilai koefisien variasi lebih besar dari 1 maka, suatu komoditas memiliki risiko harga yang tinggi. Sebaliknya apabila nilai koefisien variasi lebih kecil dari 1 maka, nilai risiko harga yang rendah. Semakin besar koefisien variasi yang dimiliki maka semakin besar tingkat risiko harga yang dihadapi.

Risiko harga yang cenderung tinggi dikarenakan permintaan terhadap cabai merah besar tetap banyak sedangkan produksi cabai berfluktuasi, sehingga mempengaruhi pada besar kecilnya harga cabai merah besar yang diterima oleh petani. Selain itu dari segi penawaran cabai pun berpengaruh pada tingkat risiko harga yang diterima. Jumlah produksi yang tidak dibarengi dengan jumlah permintaan yang tinggi, disebabkan adanya pemberlakukan PSBB dibeberapa daerah tujuan pasar. Akibatnya terjadi kelebihan pasokan dan jatuhnya harga cabai (Fajar, 2020). Risiko harga merupakan keadaan dimana harga jual hasil panen tidak sesuai dengan besarnya biaya yang dikeluarkan (Arfianti, 2017).

\section{Uji Asumsi Klasik}

\section{Uji Normalitas}

Normalitas data merupakan salah satu asumsi yang diperlukan dalam regresi linier berganda. Uji normalitas menggunakan metode probability plot. Hasil uji normalitas dapat dilihat pada Gambar 3.

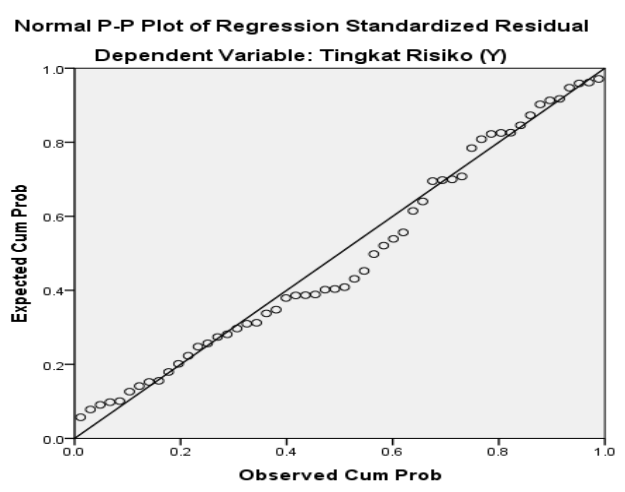

Hasil uji normalitas menunjukan bahwa penyebaran data mengikuti garisgaris diagonalnya. Artinya bahwa model regresi yang diterapkan anatara variabel bebas dengan variabel terikat terdistribusi secara normal. Regresi yang digunkan terdistribusi normalitas jika penyebaran data mengikuti garis diagonal pada sumber diagonalnya (Widarjono, 2014).

\section{Uji Multikolinearitas}

Hasil uji multikolinearitas menunjukan variabel $X$ memiliki nilai VIF lebih kecil dari 10 dan nilai tolerance lebih besar dari 0,10 maka, model regresi linier bebas dari adanya multikolinearitas dan model regresi tersebut layak untuk digunakan.

3. Uji Heteroskedastisitas

Uji heteroskedastisitas dideteksi menggunakan metode scatterplot. Hasil 
uji heteroskedastisitas dapat dilihat dari grafik scatterplot pada Gambar 4.

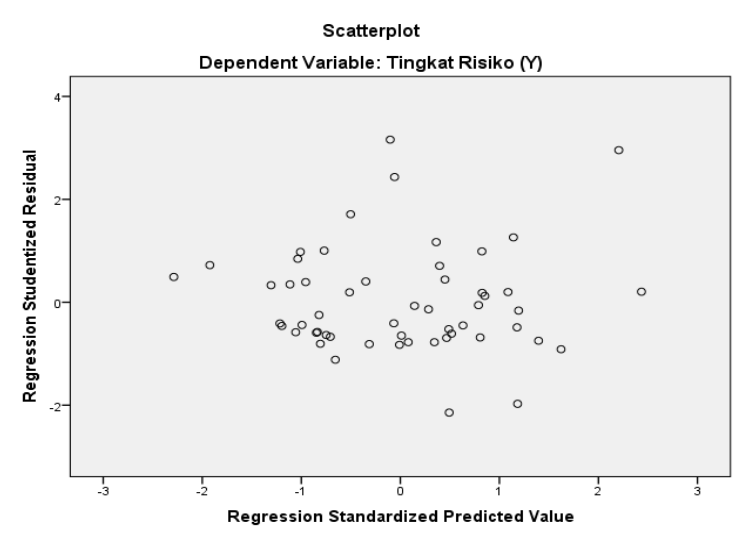

Berdasarkan Gambar 4.

Menunjukan bahwa tidak ada pola yang jelas yaitu pola bergelombang melebar dan menyempit, serta titik-titik menyebar di atas dan dibawah nilai 0 pada sumbu Y. Artinya bahwa tidak terjadi heteroskedastisitas pada model regresi yang digunakan.

$Y=-0,345-2,886 X_{1}+1,166 X_{2}+8,207 X_{3}+1,004 X_{4}+3,337 X_{5}+1,143 X_{6}+4,659 X_{7}-2,661 X_{8} \ldots$ (4)

Dari hasil regresi linier berganda menunjukan:

- Nilai konstan (a) adalah -0,345 menyatakan jika banyaknya jumlah produksi, harga produsen cabai, jumlah penduduk, harga bawang merah komplementer, harga cabai keriting substitusi, pendapatan, permintaan, dan harga cabai sebelumnya dianggap konstan, maka tingkat risiko harga cabai merah besar dapat mencapai $-0,345$

- Koefisien regresi X1 adalah -2,886 menyatakn bahwa setiap penambahan

\section{Uji Autokorelasi}

Hasil uji autokorelasi menunjukan nilai Durbin Watson sebesar 1,946. Setelah dilakukan pengujian model Durbin Watson dengan kriteria $\mathrm{dL}<\mathrm{dw}, 4$ $\mathrm{du}$ diperoleh hasil perbandingan yaitu $1,9128<1,946<2,0872$. Hal ini menunjukan bahwa nilai Durbin Watson terletak antara batas bawah (dL) dengan batas atas (4-du). Artinya model regresi linier berganda pada penelitian ini bebas dari gejala autokorelasi.

\section{Regresi Linier Berganda}

Hasil analisis regresi linier berganda menunjukan persamaan sebagai berikut : 
harga cabai merah besar sebesar $820,7 \%$

- Koefisien regresi X4 adalah 1,004 menyatakn bahwa setiap penambahan 1\% pada banyaknya harga bawang merah komplementer akan meningkatkan tingkat risiko harga cabai merah besar sebesar 100,4\%

- Koefisien regresi X5 adalah 3,337 menyatakn bahwa setiap penambahan $1 \%$ pada banyaknya harga cabai keriting substitusi akan meningkatkan tingkat risiko harga cabai merah besar sebesar $333,7 \%$

- Koefisien regresi X6 adalah 1,143 menyatakn bahwa setiap penambahan $1 \%$ pada banyaknya pendapatan akan meningkatkan tingkat risiko harga cabai merah besar sebesar $114,3 \%$

- Koefisien regresi X7 adalah 4,659 menyatakn bahwa setiap penambahan $1 \%$ pada banyaknya permintaan akan meningkatkan tingkat risiko harga cabai merah besar sebesar $465,9 \%$

- Koefisien regresi X8 adalah -2,661 menyatakn bahwa setiap penambahan $1 \%$ pada banyaknya harga cabai sebelumnya akan menurunkan tingkat risiko harga cabai merah besar sebesar $266,1 \%$

\section{Uji t (Uji Parsial)}

Adapun hasil penelitian faktor-faktor yang mempengaruhi risiko harga berdasarkan analisis regresi linier berganda tersaji dalam table 1 .

Table 1. Hasil analisis faktor-faktor yang mempengaruhi risiko harga

\begin{tabular}{|l|l|r|r|r|}
\hline \multicolumn{2}{|c|}{ Model } & \multicolumn{1}{c|}{$\mathrm{t}$} & \multicolumn{1}{c|}{ Sig. } & \multicolumn{1}{c|}{$\mathrm{r}^{2}$} \\
\hline \multirow{1}{*}{} & (constant) & -.164 & .870 & \\
\cline { 2 - 5 } & Produksi cabai $\left(\mathrm{X}_{1}\right)$ & -2.200 & $.033^{* *}$ & 0,047 \\
\cline { 2 - 5 } & Harga Produsen cabai $\left(\mathrm{X}_{2}\right)$ & .642 & $.524^{*}$ & 0,013 \\
\cline { 2 - 5 } 1. & Jumlah penduduk $\left(\mathrm{X}_{3}\right)$ & 1.742 & $.088^{* * *}$ & 0,0096 \\
\cline { 2 - 5 } & Harga bawang komplementer $\left(\mathrm{X}_{4}\right)$ & .559 & $.579^{*}$ & 0,02 \\
\cline { 2 - 5 } & Harga cabai keriting substitusi $\left(\mathrm{X}_{5}\right)$ & 2.352 & $.023^{*}$ & 0,00005 \\
\cline { 2 - 5 } & pendapatan $\left(\mathrm{X}_{6}\right)$ & 2.673 & $.010^{*}$ & 0,09 \\
\cline { 2 - 5 } & Permintaan $\left(\mathrm{X}_{7}\right)$ & 2.310 & $.026^{*}$ & 0,036 \\
\cline { 2 - 5 } & Harga cabai sebelumnya $\left(\mathrm{X}_{8}\right)$ & -2.242 & $.030^{*}$ & 0,058 \\
\hline
\end{tabular}

Keterangan: *Signifikan 5\%, **Signifikan 15\%, ${ }^{* * *}$ signifikan 25\%. Sumber: Data sekunder diolah, 2021

. Berdasarkan hasil penelitian pada uji t. menunjukan bahwa variabel bebas terhadap variabel terikat sebagai berikut:

1. Jumlah produksi (X1) memiliki nilai sig sebesar 0,034 dengan taraf kepercayaan
$85 \%(a=0,15)$, nilai sig $<0,05$ maka, H0 ditolak dan H1 diterima yang berarti produksi cabai berpengaruh secara signifikan pada tingkat risiko harga cabai 
merah besar. Hal ini dapat terjadi sebab panjangnya alur distribusi berasal dari petani hingga sampai ke konsumen, akibatnya adanya penambahan biayabiaya selama proses distribusi sehingga mengakibatkan harga cabai merah besar tinggi meskipun produksinya banyak. Hasil penelitian Suryanawati \& Geltrie (2020) menunjukan bahwa jumlah produksi cabai merah berpengaruh terhadap harga cabai merah besar dan bernilai negatif. Bahwa semakin tinggi jumlah produksi maka semakin rendah tingkat risiko harga yang diterima, hal ini karena provinsi jawa barat menjadi sentra produksi cabai merah besar yang mendominasi pasokan pasar di berbagai wilayah di Indonesia. Variabel jumlah produksi dapat menyebabkan harga turun dan berfluktuasi sehingga dapat menyebabkan terjadinya risiko harga.

2. Harga produsen cabai (X2) dengan nilai sig 0,542 > 0,05 maka H0 diterima dan menolak H1, maka variable harga produsen cabai tidak berpengaruh secara signifikan pada tingkat risiko harga. Hal ini terjadi akibat dari sulitnya petani untuk memprediksi dan penetapan harga karena rata-rata petani menjual pada tengkulak yang telah mematok harga. Dilihat dari kebijakan pengaturan agen-agen dalam pengendalian harga cabai belum optimal, sebab bentuk pengawasan dan harga yang ditetapakn pada tingkat produsen belum terjaga (Naziulloh et al, 2021).
3. Jumlah penduduk (X3) nilai sig 0,088 dengan taraf kepercayaan 75\% ( $\alpha=0,25)$ maka nilai sig 0,088 < 0,25. Hal ini menujukan bahwa H0 ditolak dan H1 diterima, maka jumlah penduduk berpengaruh signifikan pada tingkat risiko harga. Jumlah penduduk mencerminkan potensi banyaknya konsumen yang akan membeli suatu barang, sehingga jika jumlah penduduk bertambah maka kebutuhan pangan semakin meningkat. Sejalan dengan penelitian (Dewi, 2009) bahwa variabel jumlah penduduk berpengaruh signifikan terhadap permintaan cabai merah besar. Besar kecilnya permintaan tentu berpengaruh pada harga cabai sehingga menyebabkan adanya risiko harga cabai.

4. Harga bawang merah komplementer (X4) nilai sig 0,576>0,05 maka, H0 diterima dan menolak H1, yang berarti bahwa variable harga bawang tidak berpengaruh secara signifikan terhadap tingkat risiko harga cabai merah besar (Y). Hal ini disebabkan karena selera maupun minat konsumen membeli bawang merah tidak berpatokan pada harga cabai merah besar. Hal ini sesuai dengan pendapat Rasul et al., (2013) bahwa harga barang pelengkap juga akan mempengaruhi keputusan seorang konsumen untuk membeli atau tidaknya barang utamanya.

5. Harga cabai keriting substitusi (X5) nilai sig 0,023<0,05, maka H0 ditolak dan menerima H1, yang berarti bahwa variable harga cabai merah keriting berpengaruh 
secara signifikan terhadap tingakt risiko harga cabai merah besar (Y). Suatu komoditas dikatakan sebagai komoditas pengganti apabila komoditas tersebut mampu menggantikan komoditas lain. Pada penelitian ini cabai merah keriting dianggap sebagai komoditas pengganti cabai merah besar.

6. Pendapatan (X6) nilai sig $0,01<0,05$, maka $\mathrm{H} 0$ ditolak dan menerima $\mathrm{H} 1$, yang berarti bahwa variable pendapatan berpengaruh secara signifikan pada tingkat risiko harga cabai merah besar ( $(Y)$. Ini karena pendapatan mempengaruhi daya beli masyarakat. Cabai merah besar merupakan komoditas yang banyak digemari oleh masyarakat sehingga jika pendapatan naik maka masyarakat cenderung membeli cabai lebih banyak dari sebelumnya (Susilowati, 2020).

7. Permintaan konsumen (X7) nilai sig 0,026 $<0,05$, maka H0 ditolak dan menerima H1, yang berarti bahwa variable permintaan konsumen berpengaruh secara signifikan terhadap harga cabai merah besar ( $(\mathrm{Y})$. karena jumlah permintaan konsumen pada suatu barang terjadi berdasarkan pola konsumsi masyarakat terhadap makanan. Mekanisme harga adalah proses yang berjalan atas gaya (kekuatan) Tarik menarik antar konsumen-konsumen dan produsen-produsen yang bertemu dipasar. Pada suatu waktu, harga barang akan naik karena gaya Tarik konsumen menjadi lebih kuat (konsumen meminta lebih banyak barang). Sebaliknya harga suatu barang turun apabila permintaan para konsumen melemah (Juniarsih, 2016)

8. Harga cabai sebelumnya (X8) nilai sig 0,03 $<$ 0,05 maka H0 ditolak dan menerima H1, yang berarti bahwa variable harga cabai merah sebelumnya berpengaruh secara signifikan terhadap tingkat risiko harga cabai merah besar $(\mathrm{Y})$. Hasil penelitian Himawan \& Puryantoro (2019), variabel harga cabai sebelumnya berpangaruh signifikan terhadap tingkat risiko harga. Serta memiliki kontribusi negatif, yang berarti bahwa variabel harga cabai sebelumnya mempunyai hubungan yang berlawanan arah dengan tingkat risiko harga.

\section{Uji F (Uji Simultan)}

Table 2. Hasil uji F

\begin{tabular}{|rl|r|r|r|r|r|}
\hline Model & \multicolumn{1}{|c|}{$\begin{array}{c}\text { ANOV of } \\
\text { Squares }\end{array}$} & df & $\begin{array}{c}\text { Mean } \\
\text { Square }\end{array}$ & F & Sig. \\
\hline \multirow{3}{*}{1} & Regression & 19.829 & 8 & 2.479 & 4.054 & $.001^{\mathrm{b}}$ \\
& Residual & 27.514 & 45 & .611 & & \\
& Total & 47.344 & 53 & & & \\
\hline
\end{tabular}

Berdasarkan Tabel 2 diatas dapat dilihat bahwa secra serempak variabel bebas ternyata berpengaruh secara signifikan terhadap tingkat risiko harga cabai merah 
besar di Provinsi Jawa Barat. Hal ini dapat dilihat dari nilai signifikansi sebesar 0,001 dengan menggunakan taraf kepercayaan 95\% sehingga tingakt kesalahannya (a) sebesar 0,05. Selain itu berdasarkan hasil uji diperoleh nilai F hitung sebesar 4,054 sedangkan nilai $F$ tabel sebesar 2,15. Nilai $F$ hitung 4,054 > 2,15 Ftabel. Maka dapat disimpulkan H0 ditolak dan H1 diterima yang berarti secara simultan variabel jumlah produksi cabai $(\mathrm{X} 1)$, harga produsen cabai (X2), Jumlah penduduk (X3), Harga bawang merah komplementer (X4), Harga cabai merah kriting substitusi (X5), Pendapatan (X6), Permintaan (X7), dan Harga cabai merah sebelumnya (X8) berpengaruh signifikan secara bersama-sama terhadap tingkat risiko harga cabai merah merah $(\mathrm{Y}) \mathrm{di}$ Provinsi Jawa Barat.

\section{Koefisien Determinasi}

Table 3. Hasil uji koefisien determinasi Model Summary ${ }^{b}$

\begin{tabular}{|l|l|l|l|l|l|}
\hline Model & \multicolumn{1}{|c|}{$\mathrm{R}$} & $\mathrm{R}$ Square & \multicolumn{1}{|c|}{$\begin{array}{c}\text { Adjusted R } \\
\text { Square }\end{array}$} & $\begin{array}{c}\text { Std. Error of the } \\
\text { Estimate }\end{array}$ & Durbin-Watson \\
\hline 1 & $.647^{\mathrm{a}}$ & .619 & .616 & .78194 & 1.946 \\
\hline
\end{tabular}

a. Predictors: (Constant), Harga cabai sebelumnya (X8), Harga Produsen cabai (X2), Produksi cabai (X1), pendapatan (X6), Harga cabai keriting substitusi (X5), Permintaan (X7), Jumlah penduduk (X3), Harga bawang komplementer (X4)

b. Dependent Variabel: Tingkat Risiko (Y)

Regresi linier dengan lebih dari dau variabel bebas lebih baik menggunakan nilai Adjusted R Square sebagai koefisien determinasi (Himawan et al, 2019) berdasarkan hasil uji koefisien determinasi, diperoleh angka Adjusted $\mathrm{R}$ Square sebesar 0,616 atau 61,6\%. Hal ini menunjukan bahwa presentase sumabangan pengaruh variabel bebas (X1..X8) terhadap variabel terikat (Y) sebesar $61,6 \%$. Sedangkan sisanya sebesar $38,4 \%$ dipengaruhi atau dijelaskan oelah variabel lain yang tidak dimasukan dalam model penelitian ini.

\section{KESIMPULAN}

Berdasarkan hasil analiss data dan pembahasan maka dapat ditarik kesimpulan bahwa tingkat risiko harga cabai merah besar di Provinsi Jawa Barat ke dalam kategori risiko besar. Faktor-faktor yang mempengaruhi tingkat risiko harga cabai merah besar di Provinsi Jawa Barat adalah jumlah produksi, jumlah penduduk, harga cabai keriting substitusi, pendapatan, permintaan dan harga cabai sebelumnya.

\section{DAFTAR PUSTAKA}


Aisyah \& S, K. (2017). Ekonomi Mikro Aplikasi Dalam Bidang Agribisnis. Makassar: IntiMediatama.

Arfianti, N. (2017). Analisis Risiko Usahatani Cabai Merah Dengan Pola Tanam. Universitas Muhammadiyah Yogyakarta.

Astuti R, A. F. (2018). Analisis Risiko Harga Komoditas Sayuran Unggulan Di Indonesia. Forum Agribisnis Institut Pertanian Bogor, $8(1): 35-60$.

Dewi, R. K. (2017). Risiko Dalam Manajemen Usahatani. Denpasar: Universitas Udayana.

Fajar, T. (2020, September 2020). Stok Cabai pada September-Oktober Diprediksi hanya Tersedia 9.000 Ton. Retrieved from https://economy.okezone.com/re ad//stok-cabai-pada-septemberoktober-diprediksi-hanya-tersedia9-000-ton

Himawan, P. \&. (2019). Analisis FaktorFaktor Yang Mempengaruhi Harga Cabai Rawit Di Pasar Besuki (Studi Kasus Di Desa Besuki Kecamatan Besuki Kabupaten Situbondo). AGRIBIOS Jurnal Ilmiah, 17(1) : 7-14. Juniarsih, T. (2016). Analisis Faktor-Faktor yang Mempengaruhi Harga Cabai Merah (Capsicum annuum L) di
Sumatera Utara. Medan: Universitas Sumatera Utara.

Mohammed, B. A. (2016). Profitability in Chili Pepper Production in Kaduna State, Nigeria. British Journal of Applied Science and Technology, 12(3): 1-9.

Priangan Portal Informasi Harga Pangan Jawa Barat. (2021, January 1). Priangan Portal Informasi Harga Pangan. Retrieved April 15, 2021, from Priangan Portal Informasi Harga Pangan: http:/ / priangan.org/

Rasul, A. A. (2013). Ekonomi Mikro. Jakarta: Mitra Wacana Media.

Salim, M. (2016). Analisis Risiko Harga Cabai Di Pasar Keramat Jati. Bogor: Institut Pertanian Bogor.

Sekaran, U. (2016). Research Methods for Business: Metodologi Penelitian Untuk Bisnis, buku 2. Jakarta: Salemba Empat.

Shinta, A. (2011). Ilmu Usahatani. Malang: Universitas Brawijaya Press.

Siahaan, H. (2013). Manajemen Risiko. Jakarta: Elex Media Komputindo.

Sijabat, T. J. (2020). Analisis Risiko Harga Cabai Merah (Capsicum annuum L) Di Kota Medan. Medan: Universitas Sumatera Utara.

Sriyadi. (2014). Risiko Usahatani. Yogyakarta: LP3-UMY. 
Statistik, B. P. (2020). Provinsi Jawa Barat Dalam Angka 2020. Bandung: Badan Pusat Statistik Provinsi Jawa Barat. Sukirno, S. (2013). Mikro Ekonomi Terori Pengantar. Jakarta: Raja Grafindo Persada.

Susilowati, G. \&. (2020). Dampak Pandemi Covid-19 Terhadap Produksi, Harga Serta Konsumsi Cabai dan Bawang Merah. Pusat Sosial Ekonomi dan Kebijakan Pertanian.
Widarjono, A. (2014). Teori dan Aplikasi Untuk Ekonomi dan Bisnis Edisi kedua. Yogyakarta: Ekonisia Fakultas Ekonomi Universitas Islam Indonesia.

Winardi \& Paul, A. (2019). Pengantar Ilmu Ekonomi Pembahasan Buku Economics an introductory analysis. Jakarta: Budi Kemuning.

Yogi, \& Ratnaningtyas, S. (2020). Pengantar Ekonomi Pertanian. Bandung: Yogi \& Sudrajati Ratnaningtyas. 